\title{
A Comparative Analysis on Indonesian 2013 and Slovenian 1999 Kindergarten Curricula
}

\author{
Laode Muhammad Firman Guntur*
}

\author{
Monash University
}

\begin{abstract}
For about 2 decades, Slovenian preschools have implemented curriculum established in 1999 without any major reform ever since. Meanwhile, Indonesia has changed its school curriculum three times over the same period (2004, 2006, and 2013). The latest change brings with it the reform of Indonesia's preschool curriculum. Both countries share context of which preschool education is not made compulsory and the prescribed preschool age range is 1 to 6 years old. This research attempted to compare Indonesian 2013 preschool curriculum (K-13) with Slovenian 1999 curriculum in terms of their development and implementation while also trying to uncover the embedded cultural values and influences on both curricula and how they have impacted different shareholders. In doing so, this research was conducted by reviewing the collated official curriculum documents published by education ministry of the two countries while analysing facts, statistics and issues emerged from related studies and articles. Similarities were found in terms of them functioning as the foundation for the education system, optimised parents' roles, the flexibility of implementation, and their philosophical bases. Slight to significant differences were found in the included parties within the designing processes, the documented and elaborated goals, the privileged groups, and their effects on teachers, staff and school institutions in the implementation basis. The findings suggest that Indonesian curriculum needs to be made more practical instead of being too philosophical while gradual and continuous evaluation in necessary aspects is more recommended than total reforms which tend to result in longer adaptation and transition process.
\end{abstract}

Keywords: Indonesian Preschools, Kindergarten Curriculum, Slovenian Preschools

\section{Introduction}

Indonesia and Slovenia are two among many countries included in the Programme of International Students Assessment (PISA) which is initiated by the Organisation for Economic Co-operation and Development (OECD). Both countries have since constructed their education design and development with the result of the assessments becoming one of the main foci. The PISA itself are assessments measured from 15-16 years old student samples in every participating country on three domains: science, reading and math but the results are often perceived as what have been achieved by the entire education levels including levels (preschool and elementary) prior to that age.

The PISA 2012 results showed Indonesia rank 63rd from 64 countries while neighbouring countries such as Malaysia and Thailand ranked higher (OECD, 2015). In the same period, Slovenia ranked in the top third of participating countries doing outstandingly well in science and math. The consistency of progress that Slovenia have shown especially in 2015 (OECD, 2018) where the country ranked 13 out of 72 countries has made the country become some particular attractions for academic investigations.

Meanwhile, the poor PISA results for Indonesia have inspired the advocates toward a reform of the country's curriculum. In 2013, Indonesia established a new curriculum platform which is popularly known as K-13 which included the new kindergarten curriculum. Historically, preschool education in Indonesia has had its own curriculum in 2006. However, the K-13 brought with it the changes in fundamental aspects such as practices and policies. In the same course in Slovenia, curriculum reform has not been at its importance. Since 1999, when the first official kindergarten curriculum was established, Slovenia have rather opted on evaluating the 
curriculum based on gradual achievements and fixed where (and when) improvements are considered necessary than opting for a total reform.

At a glance, Slovenia and Indonesia arguably share quite similar context and views when it comes to preschool education. Both countries assure the importance of kindergarten as the foundation level of the countries' education system with that being the first official and formal education students acquire in their lives. Preschool ages are also equally perceived ranging at 1 to 6 years old. Despite generally parents are being offered half-day program, they have the option to register their children to preschools with full-day program as well. These contextual similarities are considered integral factors in comparing the preschools curricula which are currently implemented in the two countries respectively.

Slovenia's consistency in kindergarten curriculum and progress they have achieved in PISA results are arguably what Indonesia, as a country, should look at if they are to achieve the same progress and to establish an effective yet lasting curriculum. Researches on this Slovenian curriculum have become attractions in academia especially in the past decade (Vonta, 2007; United Nations Educational, Scientific, and Cultural Organization [UNESCO], 2015) proving yet again that regardless of its age, their curriculum, especially in terms of the practices and policies, has been on the right track.

This comparative study tries to uncover the crucial issues, policies and practices in different layers which differ the curricula one from the other as well as providing perspectives from various shareholders. This research seeks to expose the process of designing, introducing and developing the curriculum, the participating parties, the stated and unstated purposes within the curriculum documents, the philosophical bases and influences in its practices and policies, while also trying to investigate the groups that are being benefited, privileged, and/or probably losing in its implementation.

\section{Methodology}

Since the main objectives of this research are to synthesise the similarities and differences between the two curricula in terms of practices and policies, to assess and to evaluate how some curriculum features can be learned and installed from one to the other, it is carried out with a comparative approach. This research is conducted by critically comparing the official kindergarten curriculum documents obtained from Ministry of Education (MoE) official websites of both countries, studying findings from previous studies on the same focus, and analysing statistics from related sources. In terms of implementation and influences of the curricula on several groups, this research also discusses emerging issues from reliable online news articles. This research is categorised as literary research, hence there is no particular population and samples identified within the course of this study.

\section{Findings and discussion}

\section{Participating Parties in and The Process of Curriculum Design}

The development of both curricula and the included parties are observable in two stages. As intended curriculum, both curriculum documents are designed by the selected government authorities. In Slovenia, the body is called Kindergarten Curriculum Commission that work under the Ministry of Education, Science, and Sports (MESS) while in Indonesia it is Direktorat Pembinaan Pendidikan Anak Usia Dini (Preschool Education Development Directorate) which work under Ministry of Education and Culture (MoEC). Members of both bodies are mostly educational researchers. For Implemented curriculum and its development, Slovenian government employ not only educational practitioners (e.g., lecturers and teachers) with preschool education expertise and experience, but also more interestingly, arts and sports education experts. In both countries, the implementation of flexible socio-constructivism approach provides rooms for teachers and schools to develop 
the curriculum in institutional level. In these stages, non-educational groups (e.g., parents and business) are not involved. Though, these groups remain influential and considered as pressure groups which according to Van den Akker (2004) can be either the proponents or opponents of the curriculum.

The process and rationale of creating and developing both curricula are different. The kindergarten curriculum 2013 in Indonesia is designed as the nation's reactive response to the poor 2012 PISA result which revealed that 15 years-old students in Indonesia rank very low in mathematics, science and reading (63 of 64) comparing to other participating nations (OECD, 2013). The nation has since realised that changes should take place even from the foundation levels (MoEC, 2015a). Hence, the curriculum 2013 (K-13) platform also brings massive changes in the preschool curriculum which, then, advocate great changes in perspectives of executing the curriculum at the grassroots level..

The integration of K-13 within the educational system is explained in Permendikbud (MoEC regulation) number 602014 article 7 which rules that the implementation of K-13 in every pre-school institution must refer to constitution (MoEC, 2015a). The regulation elaborately insists that every institution (teachers, principals, and staffs) must participate in training focusing on the curriculum implementation. There is also documented guidelines for implementing the curriculum.

Though it is strictly ruled, MoEC (2015a) also emphasise a privilege that institutions and teachers are given autonomy to develop the curriculum based on characteristics and uniqueness of the schools and the surrounding values. Continuous development and upgrading of the curriculum are also ruled to happen in institutional level for teachers and staffs. Throughout its implementation, regular monitoring and evaluation are conducted and the regulation rules that government officers who are employed for these tasks must also be trained (MoEC, 2015a).

Slovenian kindergarten curriculum, on the other hand, is designed to embed analyses, proposals and solutions from the 1995 White Paper on Education in the Republic of Slovenia, The 1966 Kindergarten Act; Šlska zakonodaja I (School Legislation I) as conceptual basis (OECD, 2017). Similar to that Indonesian curriculum, the content design of this curriculum also corresponds to the entire content in education system at the upper levels. Since 1999, the publication year of this curriculum, any proposal of upgrading, complementing, and changing to the curriculum has been based on recent kindergarten students' achievements. To date, this curriculum document published in 1999 has not changed a lot and is still being enacted as guidelines for understanding and implementing kindergarten curriculum in Slovenian preschools (UNESCO, 2015; OECD, 2017). According to PISA 2015 result (OECD, 2018), Slovenia ranks high at 13 of 72 participating countries. As it is also believed to influence achievement in Indonesian context, this achievement should arguably be a product of successful education system from the foundation level. McWayne, Fantuzzo and McDermott (2004) confirm this assumption in their study, finding that achievement observed in children as a result of preschool education describes potentiality of their future academic successes in such early stage.

\section{Introduction and Distribution of the Curriculum, and Reception from Various Groups}

The introductions of both curricula are based on different motives but with one common goal, which is to build strong foundation for their educational system. Curriculum documents are published in the official websites of each education ministry. These documents are spread and made available online and offline giving easy access to teachers, academics, parents and other interested parties. In Indonesia, the curriculum comes with basic design and curriculum structure, as well as guidelines on activities designing, operational standard, behaviour development, classroom management, thematic development, lesson planning, teaching and learning management, and assessments ('Buku Kurikulum 2013 PAUD dan Pedoman Pembelajaran PAUD’, 2017).

The introduction of K-13 for Indonesian pre-schools provokes different responses from various groups. Through government funded and self-funded seminars, workshops, and training and continuous upgrading, both teachers 
and academicians have become familiar with the curriculum. Combining the guidelines and teachers' autonomy, pedagogy has become more creative and effective in catering students' needs including those with special needs (Wijaya, 2015). However, descriptive assessment required by the curriculum adds burden to teachers' workload and limited time is felt unideal to observe students' social activities (Maba, 2017). Moreover, questions are always raised about the balance between teachers' welfare and their work demands (Sulisworo, Nasir and Maryani, 2017). These pros and cons from teachers' behalf and the issues that surround and impact the teaching practices are addressed in the positioning of teachers as either benefited or losing group.

Since the introduction, a number of studies and publications on pre-school education improves focusing on the implementation and its flexibility in different settings (e.g., Rindaningsih, 2012 (in the designing stage); Fauziddin, 2016; Rozalena and Kristiawan, 2017) have been carried out. These discoveries and academic attractiveness could mean that the educational researchers have received the curriculum and engaged productively with its intention and implementation.

One of the main characteristics of this curriculum is the optimisation of parents' roles in the process of learning (MoEC, 2015b). It sees parents as teaching partners. Parents are expected to fill the gaps of teaching their children after 15 hours teaching per-week at schools which is known as nursery programs. Affrida (2017) pinpoints that within K-13, parents play double roles namely role models and facilitators - the roles.that previously limited only to teachers. Parents are often invited to observe students learning at schools and given easy access to the curriculum, in which they are privileged to discuss and voice their concerns. In fact, their voices are heard and several changes in implementation have been done based on these concerns in terms of assessments, topics and activities appropriateness, and more parents' involvement in curriculum discussion and extracurricular activities (Affrida, 2017).

Since the flexible K-13 is developed regarding to uniqueness and characteristics of norms and values surrounding preschool institutions, business and religious groups are also concerned. Nowadays, though it is not compulsory, more parents enrol their children in preschools including private preschools that represents their religion. The growing number of religion-based preschool since the introduction of K-13 proving that religious groups are aware of the values and cultures that their children get exposed to at schools. In 2017, there are approximately 238.000 preschools across the country with only about 6000 of those are government schools (Antara, 2018). Most of other preschools are private and religion-based. This indicates that the flexibility of preschool curriculum has caught attention of business and private sectors in terms of avenues for opening institutions with such tempting potential market. The learning methods (e.g., Montessori, project-based, Reggio Emilio, and BCCT) used in these schools are not uniform and those offered differences are considered the bargaining power from the business perspectives.

Slovenian curriculum document, slightly differently, content-wise covers global goals, principles, children's knowledge development, learning description in preschool ages, activities and content samples, and specific goals derived from different subjects namely math, nature, language, movement, art, and society (Vonta, 2007). MESS (1999) has established principles of introducing the curriculum including permanent training to all functional and managerial staffs, accurately prescribed conditions of its implementation which are designed immediately and gradually, ideal conditions for catering students with special needs, and guides to monitoring, planning and analysis to the described conditions.

The principles of professional responsibilities and autonomy embedded in this curriculum grant flexibility for staffs and teachers. Though teachers are expected to make their own adjustments in reflecting on specific yet various conditions in their teaching, the curriculum provided them with wide range of contents, strategies, and activities to implement. Using their judgements, they may complement the curriculum independently while accordingly aligning with national core curriculum. Permanent training mentioned above could prepare teachers and staff better with such regular dealings. In 2015/2016 academic year, there are approximately 10,901 
educational staffs and practitioners in Slovenian preschools with the ratio of 8 students per 1 professional and staff (The Republic of Slovenia Statistical Office [SURS], 2016).

Large number of national (e.g., OECD, 2017) and international scale studies (e.g., Vonta, 2007; UNESCO 2015) have been conducted on the curriculum proving its attractiveness for academia. These studies highlight the accomplishments of this curriculum for its success as the foundation to educational system leading to such a high rank in PISA 2015. Moreover, the curriculum principles have been studied in several countries especially those with the similar socio-constructivism approach.

Similar to Indonesia, parents are considered as working partners. The embedded principles within the curriculum related to working with parents are; easy access of curriculum information, rights for information exchange and discussion with teachers and counselling services, rights for gradual introduction of offered programs, rights for participation in activities planning (with agreement from preschool teachers), and rights for continuous and systematic briefing for these rights (MESS, 1999). Parents are gradually made aware of their rights and responsibilities. For students with special needs, professional care services are prescribed by the curriculum (UNESCO, 2015). These privileges are what now becoming examples in curriculum development in many countries.

From business perspectives, opening private institution in Slovenia is not popular and not as easy as that in Indonesia. In fact, the cost is very expensive due to many regulations it is obliged to pass for legalisation and accreditation, and private preschools are seen by parents as lacking tradition which results more trust to public schools (Vonta, 2007). This phenomenon proves, to some extent, that there is a show of pride toward identity and nationality from the parents which they expect to grow within their next generations.

In 2016, only $9 \%$ of preschools are privately-owned or run by private sectors (Republic of Slovenia Statistical Office [SURS], 2016). The spread of students is shown down below in table 1 in which only less than $2.5 \%$ of children attended private schools. Considering the previously discussed perspective, this number indicates that private preschools are less favoured by parents to enrol their children and also indicates its financial affordability. Children aged 4-6 years old enrolment in Slovenian preschools is also very high. This indicates that parents are mostly aware of the necessity of sending their children who are in golden age (according to Piaget's cognitive development theory).

Table 1. Kindergarten, Slovenia, school year 2015/2016

\begin{tabular}{|l|l|l|l|l|}
\hline \multirow{2}{*}{} & \multicolumn{2}{|l|}{ School year 2015/2016 } \\
\cline { 2 - 5 } & $\begin{array}{l}\text { Kindergarten with } \\
\text { their units }\end{array}$ & Number of children & First age period & Second age period \\
\hline Total & 978 & 85.407 & 24.413 & 60.994 \\
\hline Public preschools & 889 & 81.146 & 22.923 & 58.223 \\
\hline Private Preschools & 89 & 4.261 & 1.490 & 2.771 \\
\hline
\end{tabular}

Source: SURS

According to SURS (2016), most parents start sending their children to preschools in the age ranging from 3 to 6 years old. Participations in Slovenian preschools is very high. 4 of 5 Slovenian preschool aged children attend schools. With above $80 \%$ enrolment rate, it can be stated that awareness of the importance of preschool education exist among Slovenian parents. This also indicates that the enacted Slovenian preschool curriculum and education system in general has succeeded in gaining parents' trust as the foundation level for their children. 
Table 2. Enrolment rate of children attending kindergarten by age, Slovenia (2015/2016)

\begin{tabular}{|c|c|c|c|c|c|c|c|}
\hline & \multicolumn{7}{|c|}{ Age of children } \\
\hline & total & 1 year & 2 year & 3 year & 4 year & 5 year & $\begin{array}{l}6 \text { or more } \\
\text { years }\end{array}$ \\
\hline & \multicolumn{7}{|c|}{ Percentage $(\%)$} \\
\hline Total & 78.1 & 45.1 & 69.9 & 83.7 & 89.6 & 92.0 & 7.3 \\
\hline Boys & 79.0 & 45.4 & 70.3 & 84.5 & 90.4 & 92.7 & 9.1 \\
\hline Girls & 77.0 & 44.8 & 69.5 & 82.9 & 88.7 & 91.3 & 5.3 \\
\hline
\end{tabular}

Source: SURS

Interestingly, receptions also come from minority groups, especially the Romani minorities who are given special focus. In teaching children from these groups, teachers are given autonomy to combine the cultural values (multiculturalism) and language (bilingualism) of the given contents with the goal of 'socialisation' instead of separating them (MESS 1999; Turnšek \& Pekkarinen 2009). The principles of democratisation and plurality have built trusts for the community which results inn higher participations for Romani children in Slovenian preschools.

\section{Stated Purposes of the Curricula}

Objective of K-13 for Indonesian preschools is to optimise students' development through meaningful and enjoyable learning that helps students to reach basic competencies of affective, cognitive and psychomotor domains which will support their achievements at school and the upper levels of education (MoEC 2015c). Meanwhile, objectives extracted from Slovenian kindergarten curriculum are:

- Development of the ability to understand and accept oneself and others;

- Development of the ability to negotiate, the respect for diversity and to participate in groups;

- Development of the ability to recognise emotions and providing encouragement for emotional experiences and expressions;

- Development of curiosity, inquisitive mind, imagination, intuition and independent thinking;

- Encouragement for linguistic development and effective and creative use of speech, later also reading and writing;

- Encouragement to experience artistic works and to express oneself artistically;

- Dissemination of knowledge from different scientific fields and everyday life;

- Encouragement for physical and locomotive development;

- Development of independence in personal hygiene and care for one's health (UNESCO, 2015, p. 9)

There are similarities and differences of the compared documents. The core similarities are obvious in terms of preparing children with competencies required for upper level in education. The differences are the purposes of Slovenian curriculum are better articulated within the documents making it easy for professionals to understand 
and implement. While purposes statement of Indonesian curriculum focusses mainly on children development, Slovenian curriculum (MESS, 1999) also presents clear intentions to other shareholders such as teachers and staffs, institution, and parents.

\section{Philosophical Bases}

Both curricula are developed based on Vygostky's socio-constructivism work which sees learning and cognition occur within the interaction of individual with learning contexts (UNESCO, 2018). Indonesian curriculum has clearly stated philosophical foundations. As explained by MoEC (2015c), firstly, education system is rooted to the nation's culture in investing to current and future generation. Culture and local genius surrounding the institutions are considered background of every learning content designed to boost students' creative thinking upon the culture. Secondly, students are prospected as the creative carrier of culture. Early yet continuous exposure of culture is believed to be an approach of creating culture-loving generation who are proud and care about its regeneration. Thirdly, students are active and uniquely talented learners making the activation of eagerness and talents in their learning is imperative, including the optimisation of social interaction. Then, teachers are students' role model and facilitator since there is a belief that students tend to learn better when they have someone inspirational to look up to. Finally, approach to learning is by playing. The intended plays are those which encourage spirituality, cognition, and positive behaviour.

MESS (1999), on the other hand, state only principles of the curriculum without clear statement of philosophical foundations. Though, looking at those principles, evident philosophies and represented values can be understood. There are 16 well-rounded principles identified in the document and they cover perceived roles of stakeholders (e.g., teachers, staffs, and parents) and environment (including societies and the embedded values). Among the principles, there are values of democracy and pluralism, openness in implementation, equal opportunities and diversity awareness, right of choice and difference, respect of privacy and intimacy, and balancing between physical and intellectual development. Other principles are quite similar to those beliefs in Indonesian curriculum. The previously mentioned values are the uniqueness of this curriculum which is compatible to address in Indonesian curriculum considering its multicultural context and democratic ideology (Formen and Nuttal, 2014).

\section{Unstated Purposes and Influences on Curriculum}

Alvior (2015) explains hidden curriculum as values and norms affecting the teaching process and the enacting of curriculum in general. Though not directly prescribed within the curriculum document, they do exist and are evident. Influences could be based on political, economic, or cultural views. These influences reveal unstated purposes within the curriculum implementation. From exploring both curricula, the unstated purposes and influences on curriculum are comprehensively coexist.

In Indonesian curriculum, mentioned views are influential. As discussed earlier, politically, the curriculum is developed as reactive response to poor PISA 2012 result. There was a strong demand and a great concern from the government for immediate reform toward the nation's entire set of curricula with the goal of fixing the educational problems which, in turn, will lead to better image of the counntry following the poor PISA result. Economically, curriculum flexibility provides market for private sectors to open private preschools with various methods as offered products. In terms of religion and culture, the opening of more religion-based preschools confirms that values within the religion strongly influence the implementation of the curriculum there. These influences and purposes are not addressed in the document but facts from studies elaborated earlier in this essay may prove that they are evident.

Slovenian curriculum emphasises that everyday activities are parts of the curriculum ideal for the transfer of hidden curriculum. Generally, in every subject, children are guided to decide activities based on their interests. 
The allowance promotes values of democracy, rights of expression, and catering of special needs. Specifically, unstated purposes can be identified in learning activities per subject below:

\section{Movement}

At preschool, children learn from the natural form of movements into more complex activities. Organising games are common practices of this subject. Through games, children are expected to learn and grow complying with rules while, at the same time, improving their intellectual, emotional and social interaction domains (Swiezy, Matson and Box, 1993; Hsu, Liang, Chai, and Tsai, 2013). Irrespective to their peers' achievements, teachers always try to make children aware of their individual progress in the activities, hence they gain confidence and eliminate sense of failure and rejection. It is evident that essence of competition is not significantly promoted at this stage.

\section{Language}

Political influences are evident in this subject, especially on those minority groups where Slovenian is a second language. The government rule that collective bilingualism must be the medium of learning (MESS, 1999). The ruling means that children must also learn Slovenian as addition to their first language. The nation see language as the foundation of one's identity which also enhances sense of their belonging to Slovenia.

\section{Arts}

Through arts, children express the aesthetic ability, preference, and experience. Through art creating activities, children are expected to develop sensitivity of aesthetic features, produce polite yet critical judgement of a person or object, feel their inner independent designers/creators through experiments, and value their works (Thompson, 2002). Cultural and economic values are evident.

\section{Society}

Children are taught culture within the society. Children are made aware of their identity and relatedness (Furrer and Skinner, 2003), social integration, cooperative behaviour, and mutual understanding. Though, they are also taught that there are conditions and social problems which create certain groups coexistence are too hard to afford with the goal that children become aware of constrains in social life, especially as a cause of cultural transmission.

\section{Benefited and Losing Groups and Implication for Future Practice}

\section{The benefited groups}

Indonesian curriculum benefits:

- Teachers, in terms of the promoted autonomy and creativity resulted by the curriculum flexibility.

- Students, in terms of their different needs being catered by transformative teaching as prescribed and made possible by the curriculum.

- $\quad$ Parents, in terms of more roles can be played as they are projected as teaching partners. 
Benefited groups in Slovenian curriculum are:

- Teachers, in terms of promoted autonomy and creativity to develop the curriculum.

- Students, with different needs being catered and individual rights are fully encouraged and respected.

- Minority groups, in terms of promoted equality and equity they get with the majority Slovenian children.

Indonesian K-13 can also be problematic for some shareholders. Though benefited with autonomy and rooms for creativity, teachers may have concerns. The curriculum somewhat requires teachers with more workload of developing the content and activities comparing to previous curricula. With such workload, it is imperative to ensure teachers' welfare (Marwan, 2017). If the two are imbalance, teachers could find the salary does not worth the efforts. When teachers put less efforts, which causes pedagogy to be below the required level, students can be victims of teaching mediocrity.

In Slovenian curriculum, the business groups can be the losing party. This is due to the fact that the number of private preschools in the country is so low. The number of regulations and qualifications private schools must pass for eligibility make it very difficult and costs expensively. Parents trusts to public schools are also high making the enrolment to private schools become so low. Majority parents consider private schools to be lacking the representation of culture and values comparing to the public schools especially after the implementation of 1999 curriculum (Vonta, 2007).

\section{Conclusion}

From this comparative study, there are things to learn as realisations for future practices and policies. Firstly, government has crucial roles to ensure that teachers are facilitated with trainings and given enough attention in curriculum implementation. Secondly, teachers must be aware of their autonomy and how to maximise their pedagogical quality in teaching preschools. Thirdly, parents are teaching partners and they have roles in ensuring that learning does occur outside schools. Then, every student is special and catering their different needs prove crucial in ensuring that learning effectively happens. Last, but not least, in a multicultural society, minority groups interests have to be addressed instead of being neglected and forced to fully embraced a curriculum which does not represent them and their values.

\section{References}

Affrida, E. N. (2017). Strategi Ibu dengan Peran Ganda dalam Membentuk Kemandirian Anak Usia Pra Sekolah [Parents Strategy with Double Roles in Forming Preschool Students' Independence. Jurnal Obsesi: Jurnal $\begin{array}{llllll}\text { Pendidikan Anak Usia Dini, 1(2), } & 114-130 . & \text { Retrieved }\end{array}$ https://obsesi.or.id/index.php/obsesi/article/download/24/22

Alvior, M. G. (2015). Seven school curriculum types and their classroom implications. Retrieved from http://simplyeducate.me/2015/01/07/seven-school-curriculum-types-and-their-classroom-implications/

Antara. A. (2018, January 24). Jumlah PAUD Meningkat Pesat, Kualitas Harus Ditingkatkan [Number of Preschool Keeps Raising, Quality Must Be Enhanced]. OKEZONE NEWS. Retrieved from https://news.okezone.com/.

Cohen, L. R. (1997). I ain't so smart and you ain't so dumb: personal reassessment in transformative learning. New Directions for Adult and Continuing Education, 74, 61-68. Retrieved from https://doiorg.ezproxy.lib.monash.edu.au/10.1002/ace.7407

Collaboratory, A. R. (2016). Sir Ken Robinson - The Need for A New Model in Education. Retrieved from https://www.youtube.com/watch?v=fAb9PMs8bEg 
Fauziddin, M. (2016). Pembelajaran Agama Islam Melalui Bermain Pada Anak Usia Dini [Teaching of Islam through Playing for Preschool Students]. Jurnal Obsesi: Jurnal Pendidikan Anak Usia Dini, 2(2), 107-116. Retrieved from https://obsesi.or.id/index.php/obsesi/article/download/37/36

Figueroa, D. (2013). Truly Amazing Teacher. Retrieved from https://youtu.be/j9RDfv5OAZQ

Formen, A., \& Nuttall, J. (2014). Tensions between discourses of development, religion, and human capital in early childhood education policy texts: The case of Indonesia. International Journal of Early Childhood, 46(1), 15-31. Retrieved from https://link.springer.com/article/10.1007/s13158-013-0097-y

Furrer, C., \& Skinner, E. (2003). Sense of relatedness as a factor in children's academic engagement and performance. Journal of educational psychology, 95(1), 148. doi:10.1037/0022-0663.95.1.148

Haberman, M. (1991). The pedagogy of poverty versus good teaching. Phi Delta Kappa International, 73(4), 290-294. Retrieved from http://www.jstor.org/stable/20404620

Hsu, C. Y., Liang, J. C., Chai, C. S., \& Tsai, C. C. (2013). Exploring preschool teachers' technological pedagogical content knowledge of educational games. Journal of Educational Computing Research, 49(4), 461479. Retrieved from https://repository.nie.edu.sg/bitstream/10497/16016/1/ICCE-W2012-302_a.pdf

Kolb, D. A. (2014). Experiential learning: Experience as the source of learning and development. FT press.

Lingard, B. (2007). Pedagogies of indifference. International Journal of Inclusive Education, 11(3), 245-266. https://doi.org/10.1080/13603110701237498

LiteracyDotOrg. (2009). Paulo Freire - An Incredible Conversation. Retrieved from https://www.youtube.com/watch?v=aFWjnkFypFA

Maba, A. P. (2017). Mengembangkan kemampuan resolusi konflik interpersonal siswa melalui bimbingan kelompok dengan teknik sosiodrama [Improving resolution competence of students' interpersonal conflict through group guidance with socio-drama technique]. Proceeding at national seminar "Sketsa Pendidikan Indonesia", Semarang, Indonesia. $\quad$ Retrieved from https://files.osf.io/v1/resources/gzvu6/providers/osfstorage/59fa9bf86c613b026d51fad2?action=download\&vers ion $=1 \&$ direct\&format $=$ pdf

Marwan, A. (2017). ESP teaching challenges in an Indonesian vocational higher institution. The English Teacher, 12. Retrieved from http://www.melta.org.my/journals/index.php/tet/article/viewFile/282/179

McWayne, C. M., Fantuzzo, J. W., \& McDermott, P. A. (2004). Preschool competency in context: an investigation of the unique contribution of child competencies to early academic success. Developmental psychology, 40(4), 633. doi:10.1037/2F0012-1649.40.4.633

Ministry of Education and Culture (2015a). Kurikulum Pendidikan Anak Usia Dini: Apa, Mengapa dan Bagaimana [Preschool Curriculum: What, Why and How]. Jakarta. Retrieved from https://www.tamanpaud.com/.

Ministry of Education and Culture (2015b). Kerangka Dasar dan Struktur Kurikulum 2013 Pendidikan Anak Usia Dini [Basic Design and Structure of Preschool Education 2013 Curriculum]. Jakarta. Retrieved from https://www.tamanpaud.com/.

Ministry of Education and Culture (2015c). Pedoman Pengenalan Kurikulum Pendidikan Anak Usia Dini [Preschool Curriculum Introduction Guidelines]. Jakarta. Retrieved from https://www.tamanpaud.com/.

Ministry of Education, Science, and Sports (1999). Kindergarten Curriculum. Ljubljana. Retrieved from http://www.mizs.gov.si/.

OECD (2013). PISA 2012 results in focus: what 15-year-olds know and what they can do with what they know. Washington, DC: Author.

OECD (2017). Transition from early childhood education and care to primary education: OECD review of policies and practices for transitions from ECEC to primary education. Ljubljana. Retrieved from: http://www.oecd.org/.

OECD (2018). PISA 2015 results in focus. Washington, DC: Author. Retrieved from https://www.oecd.org/pisa/pisa-2015-results-in-focus.pdf

Republic of Slovenia Statistical Office (2018). Kindergarten, Slovenia, school year 2015/2016. Ljubljana, Slovenia: Author. Retrieved from https://www.stat.si/StatWeb/en/News/Index/5916 
Rindaningsih, I. (2012). Pengembangan model manajemen strategik berbasis (beyond center and circle Time) BCCT pada PAUD [BCCT-Based Strategy Management Development Model]. PEDAGOGIA: Jurnal Pendidikan, 1(2), 213-223. Retrieved from http://ojs.umsida.ac.id/index.php/pedagogia/article/download/42/48

Rozalena, R., \& Kristiawan, M. (2017). Pengelolaan pembelajaran paud dalam mengembangkan potensi anak usia dini [Preschool Learning Management in Developing Children's Potency]. JMKSP (Jurnal Manajemen, Kepemimpinan, dan Supervisi Pendidikan), 2(1). Retrieved from http://mhs.univpgripalembang.ac.id/e_jurnal/index.php/JMKSP/article/download/1155/983

Sulisworo, D., Nasir, R., \& Maryani, I. (2017). Identification of teachers' problems in Indonesia on facing global community. International Journal of Research Studies in Education, 6(2), 81-90. doi:10.5861/ijrse.2016.1519

Swiezy, N. B., Matson, J. L., \& Box, P. (1993). The good behavior game: A token reinforcement system for preschoolers. Child \& Family Behavior Therapy, 14(3), 21-32. https://doi.org/10.1300/J019v14n03_02

Taman PAUD (2017). Buku Kurikulum 2013 PAUD dan Pedoman Pembelajaran PAUD [Preschool 2013 Curriculum Book and Preschool Learning Guidelines]. Retrieved from https://www.tamanpaud.com/2017/01/buku-kurikulum-2013-paud-dan-pedoman.html\#

Thompson, C. (2002). Drawing together: Peer influence in preschool-kindergarten art classes. In The arts in children's lives (pp. 129-138). Springer, Dordrecht. Retrieved from https://link.springer.com/chapter/10.1007\%2F0-306-47511-1_11

Turnšek, N., \& Pekkarinen, A. (2009). Democratisation of early childhood education in the attitudes of Slovene and Finnish teachers. European Early Childhood Education Research Journal, 17(1), 23-42. https://doi.org/10.1080/13502930802688998

UNESCO (2015). Education for all (EFA): National review of Slovenia. Incheon, Republic of Korea: Author. Retrieved from http://unesdoc.unesco.org/

UNESCO (2018). Most influential theories of learning. Geneva, Switzerland: International Bureau of Education. Retrieved from http://www.ibe.unesco.org/en/

Van den Akker, J. (2004). Curriculum perspectives: An introduction. In Curriculum landscapes and trends (pp. 1-10). Springer, Dordrecht.https://doi.org/10.1007/978-94-017-1205-7_1

Vonta. T. (2007). System of early education/care and professionalisation in Slovenia. Ljubljana, Slovenia. Retrieved from https://www.ifp.bayern.de/imperia/md/content/stmas/ifp/commissioned_report_slovenia.pdf

Wijaya, S. (2015). Efektivitas Pelatihan Identifikasi Dini Keterlambatan Bicara pada Anak Usia Pra Sekolah untuk Meningkatkan Kompetensi Pedagogik Guru PAUD [Effectiveness of Training for Early Identification of Speaking Ability Lateness of Preschool Aged Children to Enhance Pedagogical Competence]. Proceeding at national seminar "Selamatkan Generasi Bangsa dengan Membentuk Karakter Berbasis Kearifan Lokal", Universitas Airlangga $\quad$ Surabaya, Indonesia. Retrieved from https://publikasiilmiah.ums.ac.id/bitstream/handle/11617/6489/13-Susiana\%20Wijaya.pdf;sequence=1 